\title{
Digitális eszközhasználati szokások vizsgálata bölcsődés gyermekek és családjaik körében - Szülők kikérdezése a pandémia idején
}

\author{
Farkas Pálma ${ }^{1}$, Schreindorfer Linda Anna ${ }^{12}$, Szabó Gábor ${ }^{13}$, \\ Varga Gyöngyi ${ }^{14}$ és Rausch Attila ${ }^{5}$
}

\author{
${ }^{1}$ ELTE Eötvös Loránd Tudományegyetem, Neveléstudomány mesterszak \\ ${ }^{2}$ Székesfehérvári Csemete Alapítvány \\ ${ }^{3}$ Fövárosi Pedagógiai Szakszolgálat és Pest Megyei Pedagógiai Szakszolgálat \\ ${ }^{4}$ Gödöllöi Egyesitett Palotakert Bölcsőde \\ ${ }^{5}$ ELTE Eötvös Loránd Tudományegyetem, Neveléstudományi Intézet
}

\begin{abstract}
Absztrakt
A kisgyermekek digitális eszközhasználata egy új és vitatott területe a pszichológiai és neveléstudományi kutatásoknak, a digitális eszközhasználatnak és tartalomfogyasztásnak nincsen kialakult szokásrendszere a kisgyermekes családokban (Konok et al., 2020). A szülők nem minden esetben vannak tisztában a kiskorú gyermekekre leselkedő veszélyekkel, esetleges kockázatokkal, miközben a szülőknek és a gyermekekkel foglalkozó szakembereknek egyaránt határozott igénye van a megfelelő eszközhasználati szokások ismeretére és tanítására (Chaudron et al., 2020). A kutatásunk célja az volt, hogy pontosabb képet kapjunk a bölcsődei ellátásban résztvevő gyermekek digitális eszközhasználatáról, valamint, hogy feltérképezzük a szülők véleményét a digitális eszközök gyermekükre gyakorolt hatásáról, egyben célunk volt megismerni prevenciós/produktív eszközhasználati nézeteiket is. Vizsgálatunk papír alapú kérdőívét 234 bölcsődés korú gyermeket nevelő szülő töltötte ki. A kutatás megmutatja a megkérdezett családok digitális eszközhasználatának főbb jellemzőit és lehetőséget teremt arra, hogy eredményeinket felhasználva a szakemberek a bölcsődés korosztály digitális eszközhasználatának preventív szemléletű, biztonságos tartalomfogyasztásra épülő ajánlásokat fogalmazhassanak meg.
\end{abstract}

Kulcsszavak: digitális technológia, bölcsődés gyermekek, eszközhasználati szokások, mobileszközök 


\section{Bevezetés}

Az elmúlt évtizedben egyre szélesebb körben váltak hozzáférhetővé és terjedtek el digitális eszközök a családokban, így a kisgyermekek is egyre gyakrabban találkoznak ezekkel, veszik kézbe és használják játékra vagy tartalomfogyasztásra a mobiltelefonokat, tableteket, számítógépeket. Nem csoda, hogy a gyermekek digitális eszközhasználatának kérdéseivel foglalkozó kutatások száma is növekvőben van. Míg óvodás korcsoportra vonatkozóan hazai kutatási eredmények régebb óta rendelkezésünkre állnak, a bölcsődés korú gyermekre irányuló kutatások köre hazánkban most kezdett el bővülni (például Koscsóné Kolkopf \& Kiss, 2020).

Az óvodásokra vonatkozó vizsgálatok arra engednek következtetni, hogy a digitális eszközhasználatnak és tartalomfogyasztásnak nincsen kialakult szokásrendszere, illemtana (Hódi et al., 2019). A fogyasztókra, legfóképpen a kiskorú gyermekekre leselkedő veszélyek, esetleges negatív kockázati tényezők nem kapnak kellő hangsúlyt, miközben számos kutatás rámutatott arra, hogy a szülőknek és a gyermekekkel foglalkozó szakembereknek egyaránt határozott igénye van a megfelelő eszközhasználati szokások ismeretére és tanítására (vö. Koscsóné Kolkopf \& Kiss, 2020). Mindemellett a digitális eszközök előnyei tagadhatatlanok, használatukkal az életünk számos területen pozitív irányban változott, ezért is fontos pedagógiai szempontból a produktív használati szokások kialakítása, módszertani ajánlások beemelése a napi gyakorlatba (Németh et.al., 2020; Visnjic-Jevtic et. al., 2021), amely mind a jelenlegi és elkövetkező felelős szülő generáció - és ezáltal gyermekeik - segítségére lehet épp úgy, mint a velük kapcsolatban álló kisgyermeknevelők, pedagógusok, szakmai szolgáltatást nyújtó szakemberek számára.

\section{Digitális technológia kisgyermekkorban}

Az elmúlt évtizedekben különösen felgyorsult a technikai fejlődés, melynek köszönhetően a digitális technológia az élet szinte minden területén jelen van: többek között az emberi kommunikáció, az oktatás és a tanulás is jelentős átalakuláson megy keresztül. A mobileszközök elterjedése pedig a kisgyermekek eszközhasználatára is hatással van (Rausch \& Pásztor, 2021). A felgyorsult digitalizáció következtében a csecsemők és kisgyermekek fejlődési környezete is jelentősen megváltozott. A családok és így már a kisgyermekek életének, mindennapjainak részét képezik a digitális eszközök, okostelefonok, számítógépek és nélkülözhetetlenné vált az internethozzáférés (vö. Csapóné, 2019).

$\mathrm{Az}$, hogy egy ember hogyan és mikor találkozik digitális eszközökkel nemcsak az életkortól, hanem nagyon is függ a gazdasági, szociokulturális háttértől, földrajzi elhelyezkedéstől, illetve egy adott országon belül egy adott térség fejlettségétől is (Lénárd, 2015). Egyre több kutatási eredmény jelenik meg a témában (például Burroughs, 2017), ezért egyre több információ érhető el a szülők számára is, ennél fogva tudatosabb, átgondoltabb lehet az 
eszközhasználattal kapcsolatos mindennapi gyakorlatuk (Bentley et al., 2016 idézi Koscsóné Kolkopf \& Kiss, 2020). Ez mégis nagy kihívást jelent a szülők számára, hiszen a mobiltelefonok, tabletek folyamatos online jelenlétet biztosítanak számukra. A modern eszközökkel egy pillanat alatt készíthetnek fotót gyermekükről és oszthatják meg azonnal ismerőseikkel a közösségi média felületein. Így lehet az, hogy sok gyermeknek már 6 hónapos korára van „digitális lábnyoma”. Azonban nem árt a dolgot továbbgondolni, vajon mennyire fog ennek örülni gyermekük, mikor már ő is tudatos eszközhasználó lesz (Steyer, 2012).

Nyilvánvaló, hogy a kisgyermekek IKT használata széles körben elterjedt az utóbbi években, valamint növekszik az egyre fiatalabbak, csecsemők körében egyaránt. Ami kevésbé érthető és sokkal kevésbé kutatott, az a legújabb alkalmazások szerepe, különösen a csecsemők digitális médiafogyasztásának vizsgálata az egyre kiterjedtebb média-ökoszisztémában. A kifejezés új keletű, melyet leginkább a résztvevői határoznak meg: tartalom-előállítók, tartalomszolgáltatók, tartalomterjesztők, forgalomirányítók, valamint a hirdetési piacon megjelenő hirdetők, médiaügynökségek, készülékgyártók és a technológia szolgáltatók (Polyák, 2015 idézi Gálik \& Csordás, 2020). Burroughs (2017) szerint - aki tanulmányában a YouTubeKids nevű alkalmazást vizsgálta -, a legnépszerűbb és legjövedelmezőbb YouTube-csatornák a teljes YouTube-platformon a gyermekek felé irányulnak. 2016-tól a YouTube megtekintések 10\%-a gyermeki szórakoztatásnak minősített tartalomból származik, és egyes országokban a szám a teljes YouTube-platform összes megtekintésének felét jelenti (Mulligan, 2016 idézi Burroughs, 2017). A technológia fejlődésével az IKT-eszközöket is könnyebb használatra tervezik. Látható, hogy a gyerekek egyre alacsonyabb életkorban kerülnek kapcsolatba a digitális eszközökkel, a különféle tartalomszolgáltatóknak, technológiai cégeknek már elsősorban a gyermekek körében van lehetőségük a felhasználói kör további bővítésére (Burroughs, 2017).

Jelenlegi élethelyzetünk, környeztünk és életvitelünk okán szinte elkerülhetetlen, hogy a gyermek ne találkozzon ezekkel az eszközökkel. Sokan gondolják úgy, hogy azért adják a gyermeknek, hogy nehogy lemaradjanak a 21. században, mások digitális gyermekfelügyelőnek használják, ha sír a gyermek, vagy ha egy hosszú útra indul a család. Az elmúlt időszak - mint például a járványügyi helyzet - komoly kihívások elé állította az eszközhasználatról tudatosan gondolkodó szülőket is. Sok szülő dolgozott otthonról, amikor szükség volt egy kis csendre, akarva akaratlanul előkerültek a digitális eszközök, hogy szórakoztassák gyermekeiket, lekössék figyelmüket (Steinwandt et al., 2020). A jóléti társadalmakban a 3-4 éves gyermekek 16\%-nak van saját tabletje, de a többiek nagy része is rendszeresen megkapja szülei digitális eszközeit. A 6-7 évesek 71\%-a használja a YouTube-ot szülői kontroll nélkül. A digitális eszközök használata már az életünk része, így szolgálhat kikapcsolódásra is. A jelenség akkor válhat problémává, amikor már csak ez jelenti a boldogságot és nincs felette kontroll. A gyermekek számára ezt a 
kontrollt a szülőknek kell megteremteni, hogy később már a gyermek saját magát tudja szabályozni. Ha a szülő nem szab határt, később a gyermek sem lesz rá képes (Fejérváry, 2020).

A Digitális Jólét Programban (Magyarország Digitális Gyermekvédelmi Stratégiája, 2016) is arról olvashatunk, hogy a tudatosság kulcsfontosságú a digitális eszközhasználat során. A szülők az internet tudatos használatával és az ott előforduló veszélyekkel sok esetben nincsenek tisztában. Amennyiben nem rendelkeznek megfelelő információkkal, úgy nem várható el tőlük az sem, hogy gyermekeiknek közvetíteni tudják azokat. A tudatos használat, a képernyő előtt eltöltött idő korlátozására már különböző applikációk is a szülők segítségére vannak, ilyen például a Digitális jóllét applikáció. Egyelőre Android-alapú eszközökre tölthető le a Google Play Áruház applikáció kínálatából (Google Play Áruház, 2020). Az említett alkalmazás használata során átfogó képet kaphatnak arról, mennyi időt töltenek a digitális térben, milyen szokások jellemzik őket. Napi lebontásban megnézhetik, melyek azok az alkalmazások, amiket a legtöbbször használnak, milyen gyakran néznek rá a telefonjukra, illetve oldják fel annak zárolását. Az alkalmazás időzítésekkel korlátozhatják, hogy naponta mennyit használják azokat, az alvásidő mód pedig emlékezteti őket, hogy zárják ki az online világot éjszakára, míg a fókuszmód segítségével egy koppintással szüneteltethetik a zavaró alkalmazásokat.

A gyermekek eszközhasználatával kapcsolatban elgondolkodtató, hogy a tech-ipar emberei közül sokan nem adnak ilyen eszközöket a saját gyermekeiknek. Ezek az eszközök úgy vannak fejlesztve, hogy akár függőséget is okozhatnak. Az alkalmazásokban a megfelelő pontokon elhelyezett ingerek célja pont az, hogy ne tegyük le az eszközt. Ezért is fontos a már fent említett tudatosság, és a napi szinten kialakított rendszerhez való következetes hozzáállás. Szintén fontosak az időközönként beiktatott nagyobb elvonulások is, amelyekre leginkább a hétvégék alkalmasak, hogy ezek a napok csak a családról szóljanak a teljes figyelem jegyében (Orlowski, 2019). Koscsóné Kolkopf Judit és Kiss Heléna (2020) tanulmányukban arra hívják fel a figyelmet, hogy az okoseszközök kezelése nem egyenlő ezek tudatos és felelős használatával. Lehet, a gyerekek már egészen kis korban képesek kezelni az érintőképernyőt, éppen ezért fontos megtanítani a gyermekeket a veszélyeire és szabályaira.

\section{Kisgyermekek digitális eszközhasználatának jellemzői}

Hazánkban a bölcsődés korú gyermekek IKT eszközhasználatára fókuszáló kutatások száma alacsony, de a Nemzeti Média- és Hírközlési Hatóság (2018) által végzett kutatás eredményei alátámasztják azt, hogy már a 3 éven aluli gyermekek IKT-eszközhasználata és digitális tartalomfogyasztása is jellemző. Az idézett kutatás célja, hogy részletesebb képet kapjanak a kisgyermekek televízió- és internethasználati szokásairól, valamint további ismereteket szerezzenek az érintett korosztály által leginkább preferált tartalmakról. Je- 
lentésükben, valamivel több, mint 1000 szülő válaszai alapján, megállapítják, hogy a három év alatti gyermekek már okostelefonon keresztül ismerkednek az internettel. A válaszokból azt a következtetést vonták le, hogy azok a szülök, akik hasznosnak tartják a különböző eszközöket gyermekük szempontjából, úgy gondolják, hogy a digitális eszközök, alkalmazások segítségével bővíthetik a legkisebbek ismereteit, fejleszthetik szókincsüket és az idegen nyelv tanulására is pozitív hatással lehet. A felmérésben résztvevő szülők az iránymutatást, a közös élményszerzést fontosnak tartják az digitális eszközök használatakor, valamint jelen szeretnének lenni a gyermek első digitális tapasztalatszerzésénél (NMHH, 2018).

Az ELTE Alfa Generáció Labor munkatársai (Konok et al., 2020) - az előbbi felméréssel közel azonos időben végzett kutatásuk alapján - hasonló adatokat közölnek. Ök 2010 után született gyermekek digitális eszközhasználati szokásait vizsgálták, de a mennyiségi mutatók mellett arra is kíváncsiak voltak, hogy az eszközhasználat hogyan hat a gyermekek fejlődésére.

A több mint ezer szülő megkérdezésével készült felmérés szerint a vizsgált korosztály 44 százaléka rendszeresen használ napi fél órában mobilt vagy tabletet, tehát a gyerekek egyre korábban és nagyobb arányban használnak digitális eszközöket, így már a kétévesek fele kütyüzik. A kutatás arra is rávilágított, hogy a gyerek mobilozási/tabletezési szokásaira a szülő véleménye és személyes példája is hatással van, tehát a digitális nevelési stílus nagyban befolyásolja a gyermek digitáliseszköz használati szokásait. A Szerzők elsőként utalnak a digitális szülői nevelési stílusok létezésére. Adatvezérelt megközelítést alkalmazva különálló digitális szülői stílusokat azonosítottak, amelyek hasonlítottak az általános szülői nevelési stílusokra (tekintélyelvü, mérvadó, elkényeztetö, elhanyagoló). Az eredmények azt igazolták, hogy az elkényeztető és mérvadó szülők gyerekei többet kütyüznek, míg a tekintélyelvűeké kevesebbet. Az eredményeikben azt fogalmazták meg, hogy a kütyüzés hatással van a gyerekek kognitív- és önkontroll folyamataira, valamint társas készségeire egyaránt. A kutatás szerint az érintőképernyős eszközök túlzott használata a fejlődő agyat túlingerli, amely többek között negatívan hat a figyelmi kontrollfunkciók, fejlődésére egyben a társas-kognitív és társas-érzelmi fejlődésre (Konok et al., 2020).

A digitális eszközök fejlődésre gyakorolt hatása megjelenik Fehérné Kovács Zsuzsanna, Kas Bence és Pintye Mária (2018) tanulmányában is, akik a nyelvi zavarok okainak feltárására irányuló kutatásuk során azt fogalmazták meg, hogy a telekommunikációs eszközök használata deformálja a szülő és a gyermek közötti interakciókat, akadályozza a kognitív és a nyelvi fejlődést. A kutatás azt az összefüggést találta, hogy a nyelvi fejlődésben késést mutató gyerekek a tipikusan fejlődő társaiknál jóval korábban kezdtek tévét nézni (7, illetve 12 hónaposan), és naponta jóval több időt töltenek a képernyő előtt (3, illetve kevesebb, mint 2 órát). Azoknál a gyerekeknél, akik 12 hónapos kor előtt kezdtek tévét nézni, és naponta 2 óránál többet töltöttek a képernyő előtt, hatszor magasabb volt a nyelvi késés előfordulása. A háttértévézés beszűkí- 
ti az anya-gyerek interakciók mennyiségét, rontja annak minőségét. Az anya romló beszédkedve, a szókincse változatosságának, színességének csökkenése a gyerek szókincsének fejlődését egyaránt hátráltatja. Azok a gyerekek, akik 18 hónapos korban, vagy már korábban használnak ilyen eszközöket, nagyobb arányban mutatnak késést a nyelvi fejlődésükben, tehát a digitális eszközhasználat komoly rizikófaktort jelent (Fehérné Kovács et al., 2018).

A kora gyermekkori digitális eszközhasználat témáját és hatásait a világ számos országában, változatos megközelítésekkel kutatják a szakemberek. Újabb és újabb eredmények jelennek meg a gyermekkori eszközhasználat hatásairól. Tsouklidis és munkatársai (2020) az elektronikus eszközök alvásra gyakorolt hatását kutatták. Az Egyesült Államokban, Kanadában, Svájcban, Norvégiában és Belgiumban végzett vizsgálatok eredményeiből arra a megállapításra jutottak, hogy összefüggés lehet a technológia nem megfelelő használata és az előforduló gyors szemmozgás (REM), a testtömeg-index (BMI) szintjének változásai, az elhízási és egyéb neurológiai hiányosságok között (Tsouklidis et al., 2020). Detnakarintra és munkatársai (2020) tanulmányukban az anya-gyermek interakciók, a szülői stílusok és az elektronikus képernyőidő közötti hosszú távú összefüggéseket vizsgálva az anya-gyermek interakciót, a szülői stílusokat és a képernyő-időt különböző életkorokban értékelték, és útelemzéseket végeztek a változók közötti kapcsolatok tisztázása érdekében. Eredményeik szerint a 18 hónapos korban megnövekedett anya-gyermek interakció pozitívan társult a kevesebb képernyőidővel 2 és 3 éves korban (Detnakarintra et al., 2020).

Érdekes felvetésekkel szolgál Benjamin Burroughs (2017) kutatása is, aki a médiaipar és a kisgyermekek mindennapi képernyőhasználatának (viewing patterns) és életének egyre növekvő kapcsolatát vizsgálta. Burroughs a YouTubeKids alkalmazásra, annak fejlesztésére és a fejlesztés szempontjaira összpontosít tanulmányában. Leírja, hogy az applikáció jóval több, mint 10 millió letöltéssel rendelkezik, és célja a fiatalok figyelmének lekötése, egyben bevétel termelése. Ezek a csatornák a feltörekvő mobil- és táblagép-technológiák "előnyeit” használva nagyon fiatal gyerekeket és csecsemőket (0-5 évesek) céloztak meg. A mobil- és táblaeszközök egy helyre fókuszálják a televíziós, számítógépes és mobil tartalmakat, melyeket a szülő így egy helyről tud szabályozni és dönteni ezek további felhasználásáról. A YouTubeKids alkalmazást létrehozók a platformot a szülők azon aggodalmára reagálva alkották meg, hogy a gyermekek túl sok felnőtteknek szóló tartalmat néznek a tágabb YouTube-hálózaton. Ezzel a gyermekeknek szánt alkalmazással a szülők ki tudják választani a felhasználó korosztályát és időkorlátját. Az eredmény azonban az, hogy a gyerekeket most közvetlenül elérik a reklámokkal, ezzel fontos szempontot hozva a kisgyermekek digitális eszközhasználati szokásait kutató tudományos diskurzusokba, miszerint az eszközhasználat révén tartalomfogyasztóvá váló alacsony életkorú gyermekek egy újabb csatornán keresztül fogyasztókká válnak. A kutatás médiatudományos szempontok mellett politika- és gazdaságtudományi megközelítésben értékeli a jelenséget. A tanulmányból kiderül, hogy 
a digitális oktatási applikációk és a gyerekeknek szánt alkalmazások már most is sokmillió dolláros iparágak, több mint 80000 oktatási alkalmazás jelenik meg az iTunesStore platformon. Burroughs úgy tartja, hogy az algoritmusok egyfajta pótszülőként szolgálhatnak, amelyek formálják a gyermek médiafogyasztási szokásait, és mind kifejezetten, mind implicit módon kondicionálják a kisgyermekek fogyasztását. A digitális eszközöket a szülői élet részének tekintik, mivel a csecsemőket és a kisgyermekeket szórakoztatják, de ha ezt a feladatot a YouTubeKids alkalmazás biztonságosnak vélt kereteire engedik át, akkor az algoritmusok segítségével egyre több és hatásosabb tartalomajánlás lép müködésbe, amely növelheti a képernyőidőt. Minél fiatalabb a gyermek, annál nagyobb hatással van az algoritmus és az alkalmazás szerkezete a megtekintési idő növelésére (Burroughs, 2017).

Kérdés persze, hogy mit tehet a szülő, ha egyfelöl fontosnak tartja gyermeke digitális tapasztalatszerzését, ám mégsem szeretné veszélynek kitenni őt. Hódi Ágnes és munkatársai (2019) tanulmányukban bemutatják, hogy a témát napirendre tűző gyermekgyógyászokat tömörítő szervezetek (Amerikai Gyermekgyógyászati Akadémia 2016; Kanadai Gyermekgyógyászati Társaság 2017) úgy látják, hogy szükséges korlátozni a gyermekek napi képernyőidejét. Javaslatukat azzal indokolják, hogy a valós, nem virtuális térben zajló interakciók pozitívabb hatást gyakorolnak a gyermekek fejlődésére és jólétére. Ugyanakkor a nagy-britanniai Gyermekgyógyászok és Gyermek-egészségügyi Szakmai Szervezete (Royal College of Paediatrics and Child Health) szerint a képernyőidő hatásmechanizmusa kontextusfüggő, számít az időszak, a tartalom, a felügyelet is, és még nem vagyunk elegendő megbízható információ birtokában, ahhoz, hogy pontosan lássuk a képernyő előtt eltöltött idő hogyan befolyásolja a gyermekek fejlődését. Ennek következtében nem is lehetséges általános, mindenre kiterjedő ajánlások megfogalmazása, azon túl, hogy a lefekvés előtti egy óra lehetőleg képernyőmentes legyen. Ugyanakkor a képernyőidő korlátozása szerintük is a tudatos médiafogyasztás része (Hódi et al., 2019).

\section{A kutatás célja és kérdései}

A kutatásunk célja pontosabb képet kapni a hazai bölcsődei ellátásban résztvevő gyermekek digitális eszközhasználatáról, továbbá megvizsgálni, hogy különböző szocioökonómiai tényezők milyen kapcsolatot mutatnak a gyermekek digitális eszközhasználatával. További célunk volt a szülők véleményének megismerése az IKT-eszközök gyermekükre gyakorolt hatásáról, valamint a szülők prevenciós/produktív eszközhasználati nézeteinek feltárása.

Az eszközhasználattal kapcsolatban általánosságban vizsgáltuk, 1. mikor jelent meg először a gyermek életében a digitális eszköz, 2. milyen gyakran használják a digitális eszközöket és mennyi időt töltenek képernyő előtt a bölcsődés korú gyermekek, 3. milyen tartalmakat fogyasztanak a gyermekek és szüleik, illetve milyen helyzetekben, milyen célból használják az eszkö- 
zöket. A szülők nézeteivel kapcsolatosan a kutatásban feltártuk, hogy 4. a szülők véleménye szerint tudatosan használják-e, valamint kontrollálják-e gyermekük digitális eszközhasználatát, 5. a szülők figyelemmel követik-e gyermekeik online jelenlétét, illetve tisztában vannak-e az esetleges kockázatokkal, negatív hatásokkal, 6. különböző szocio-ökonomiai tényezők (szülők iskolai végzettsége, lakóhely) mutatnak-e kapcsolatot a kisgyermekek digitális eszközhasználatával.

\section{A vizsgálat módszerei}

\section{Minta}

Vizsgálatunkban olyan szülők véleményét kérdeztük saját-, és gyermekük digitális eszközhasználatáról, akik jelenleg bölcsődei ellátást vesznek igénybe. A minta kiválasztásánál szempont volt, hogy abban különböző településtípusok jelenjenek meg, így fővárosi, megyeszékhelyi, nagyvárosi és kisvárosi bölcsődéket kerestünk fel, ugyanakkor mintánk nem tekinthető reprezentatívnak.

A kérdőívet 234 szülő töltötte ki, adataink kizárólag a 0-4 éves gyermekek szokásairól nyújtanak információt, mert abban az esetben is, ha a családban több gyermeket neveltek, kérdéseink kizárólag a bölcsődés gyermekre vonatkoztak. A kitöltők többsége a 31-40 éves korcsoportba tartozott (66\%), 19\% ennél fiatalabb, 15\% 40 évnél idősebb életkorú volt. 93\%-ban az édesanyák válaszoltak a kérdéseinkre.

A válaszadók többsége (65\%) felsőfokú végzettséggel rendelkezik, jelentős részben (32\%) voltak közöttük középfokú végzettségűek, kisebb részben pedig (3\%) általános iskolát végzettek. A kérdőívet kitöltők magasabb arányban élnek a fővárosban (25\%), megyeszékhelyen (19\%), 20 ezer lakosnál nagyobb nagyvárosban (25\%), valamint kisvárosban (23\%), lényegesen kevesebben községben (7\%).

A kérdőívben rákérdeztünk a kitöltők gyermekeinek számára és életkorára, ez alapján elmondható, hogy a vizsgálatban résztvevők közel 60\%-a (117 fö) egy, 34 \%-a (80 fö) kettő és 15\%-a három vagy több gyermekes családban él. A kérdőívet kitöltő szülők bölcsődei ellátásban részesülő gyermekeinek átlagéletkora - melyet hónapban adtak meg - 31 hónap (2,5 év).

\section{A kérdöív felépitése}

A kutatáshoz 43 zárt kérdésekből álló, papíralapú kérdőívet hoztunk létre, amely három tematikus részre tagolódott. A bevezető rész a szocioökonómiai kérdéseknek adott helyet, melyben az alapvető demográfiai ismérvek (például nem, életkor, gyermekek száma) mellett rákérdeztünk a szülők társadalmi-gazdasági részvételét mutató adatokra egyaránt. Így rákérdeztünk a szülő legmagasabb iskolai végzettségére, lakóhelyének, ingatlanának típusára, valamint, hogy mennyi könyvvel, és milyen típusú internet-elérhetőség- 
gel, milyen digitális eszközökkel rendelkezik a család. A második részben elsőként a szülők, majd a gyermekek digitális eszközhasználatát térképeztük fel, melyben többek között arról tájékozódtunk, naponta mennyi ideig és mire használják a digitális eszközöket, a nap mely részében használják, illetve, hogy a szabadidős célú használat során vannak-e kiemelt napszakok. A befejező harmadik rész ismét szülőkre vonatkozó kérdéseket tartalmazott, ebben a részben a digitálisezsköz használatban mutatott tudatosságra, az esetleges szabályokra, valamit a szülői attitűdre vonatkoztak kérdéseink. Ebben a blokkban megfogalmazott kérdések egy részében az óvodás életkorú gyermekek körében végzett hasonló témájú kutatás (Hódi et al., 2019) egyes kérdéseit vettük alapul. Úgy gondoltuk, hogy ezeket az információkat a bölcsődés gyermekek vonatkozásában egyaránt érdemes lehet feltérképezni, és a kapott eredményt összevetni a két korosztály tekintetében. Adatgyüjtésünk során szóhasználat tekintetében az egyszerüségre törekedtünk, de próbáltunk változatos kérdéstípusokat alkalmazni, így a kérdőív tartalmazott egyszeres és többszörös választású, feleletválasztós kérdéseket, Likert-skálát és feleletmátrixot egyaránt.

\section{Eljárások}

A kutatás során összesen 310 db kérdőív került kiosztásra, melyből 234 db kitöltött kérdőív érkezett vissza, ami 75 \%-os kitöltési, részvételi arányt jelent. A papíralapú kérdőívek kiosztását - az időigényes feldolgozás ellenére - az indokolta, hogy úgy gondoltuk, ezzel a módszertani megoldással tudjuk biztosítani bármely szocioökonómiai háttérrel rendelkező szülő elérését, azaz kérdőívünket azok a szülők is ki tudják tölteni, akik nem rendelkeznek internet hozzáféréssel, illetve nem rendelkeznek megfelelő digitális eszközökkel. 2020. október elején juttattuk el a kérdőíveket a bölcsődékbe, ahol a kiosztásban és az összegyüjtésben az intézményvezetők és a kisgyermeknevelők segítségére támaszkodtunk. Kutatásunk az ELTE PPK Kutatásetikai Bizottságának engedélyével zajlott, a vizsgálat előkészítése, az adatfelvétel és adatelemzés során a neveléstudományi kutatások kutatásetikai előírásainak megfelelően jártunk el. A részvétel anonim és önkéntes volt. A kérdőívet kiegészítette egy szülői tájékoztató és beleegyező nyilatkozat, melyben a kitöltők aláírásukkal fogadták el, hogy részt vesznek a kutatásban és ennek kapcsán adataikat - amelyek alapján személyazonosságuk nem állapítható meg - felhasználjuk a munkánk során. A kitöltött kérdőívet és az aláírt beleegyező nyilatkozatot külön-külön kihelyezett lezárt dobozokban gyüjtötte a bölcsőde, melyekbe kizárólag bedobni, de kivenni nem lehetett azokat. Ezt követően részben személyesen mentünk el és hoztuk el, részben postai úton kaptuk meg a kitöltött nyomtatványokat. Az adatrögzítést és kódolást Google Táblázatokban végeztük, a leíró statisztikai elemzésekhez, összefüggésvizsgálatokhoz az SPSS statisztikai elemzőprogramot használtunk. 


\section{Eredmények}

\section{Bölcsődés gyermekek digitális eszközhasználata}

Első kutatási kérdésünk arra vonatkozott, milyen életkorban kerültek először kapcsolatba a kitöltők gyermekei valamilyen digitális eszközzel. A választási lehetőségek életkori csoportokat tartalmaztak, mely adatait az 1. táblázatban összegeztük. Ebben látható, hogy a vizsgálatban szereplő gyermekek közül mindössze 13-an (5,6 \%) nem kerültek még kapcsolatba digitális eszközzel és elmondhatjuk, hogy a 232 kitöltő közül 200 kitöltő gyermeke már 24 hónaposan, tehát 2 évesen vagy azt megelőzően került közvetlen kapcsolatba digitális eszközzel. Ez a megkérdezett szülők gyermekeinek 85\%-át jelenti.

\section{1. táblázat}

Első digitális eszközhasználat életkor szerinti megoszlása

\begin{tabular}{lcc}
\multicolumn{1}{c}{ Életkori csoportok } & Kitöltő $(\mathbf{N})$ & Arány $(\%)$ \\
$\begin{array}{l}\text { Még nem került kapcsolatba } \\
\text { digitális eszközzel }\end{array}$ & 13 & 5,6 \\
6 hónapos kor alatt & 14 & \\
6-12 hónap & 64 & 6,0 \\
13-18 hónap & 83 & 27,5 \\
19-24 hónap & 39 & 16,8 \\
25-36 hónap & 18 & 7,8 \\
36 hónap felett került kapcsolatba & 1 & 0,4 \\
digitális eszközzel & $\mathbf{2 3 2}$ & $\mathbf{1 0 0}$ \\
\hline Összesen & & \\
\hline
\end{tabular}

Vizsgálatunkban arra is kerestük a választ, hogy a legfiatalabb korosztály naponta mennyi időt használja a családban előforduló digitális eszközöket. Gyakoriság tekintetében a különböző eszközök eltérő számot mutattak. A napi használat az okostelefonok esetében a legmagasabb ( 34 gyermek), majd a tablet (14 gyermek), és a laptop (9 gyermek) következik. A heti és hetente többszöri használat kapcsán is ez a sorrend a jellemző. A személyi számítógép, okosóra, e-book használata a korosztály szempontjából elhanyagolható. Az „egyéb” eszközök tekintetében 9 fö nevezte meg a televíziót, ők minden esetben napi használatot jelöltek meg. A képernyőidőre vonatkozó kategóriák szerinti eloszlást - melyek 1 órás intervallumban kerültek meghatározásra - a 2. táblázatban foglaltuk össze. 


\section{2. táblázat}

A gyermekek digitális eszközhasználatának idötartama

\begin{tabular}{lcc}
\hline \multicolumn{1}{c}{ Időintervallumok } & Kitöltő $\mathbf{( N )}$ & Arány $(\%)$ \\
\hline 1 óránál kevesebb & 184 & 82,9 \\
$1-2$ óra & 29 & 13,0 \\
$2-3$ óra & 7 & 3,1 \\
3-4 óra & 1 & 0,5 \\
$4-5$ óra & 0 & 0,0 \\
5 óra + & 1 & 0,5 \\
\hline Összesen & 222 & 100,0 \\
\hline
\end{tabular}

A kitöltők közül 184-en jellemzően (82,9 \%) azt válaszolták, hogy gyermekük napi 1 óránál kevesebbet ugyan, de napi szinten tölt időt digitális eszközzel, 29 gyermek (13\%) napi 1-2 órát használja a kütyüket, és összességében 9 gyermek (4,1 \%) esetében jelöltek meg naponta 2 óránál hosszabb képernyőidőt.

A kérdőívben megkérdeztük a szülőket arról, milyen digitális alkalmazásokat töltöttek le okoseszközeikre, amelyeket - adott esetben - gyermekük önállóan, illetve a szülők gyermekükkel együtt is használnak. A letöltések között volt kapcsolattartó applikáció, mint a Messenger, Viber, Skype. Több szülő írta a YouTube, YouTubeKids, NetflixKids alkalmazásokat, amelyeket leginkább a mesék, dalok, mondókák miatt használják. Továbbá logikai fejlesztő, készségfejlesztő, angol nyelvi fejlesztő játékokat, puzzle, rajzoló, színező, formakirakó, állathangokat utánzó programokat töltenek le digitális eszközeikre (ezeknek az applikációknak nem adták meg a nevét). A kitöltők között voltak, akik meg is nevezték a letöltött applikációt, mint a BookrKids, HeyKids, Baby Tv, Sago Mini, BimiBoo, Talking Tom, Happy Touch, Bogyó és Babóca, illetve a TikTok. A szülők által megnevezett applikációkból arra következtethetünk, hogy a gyermekek leginkább meséket néznek és fejlesztőjátékokat játszanak a digitális eszközökön.

Arra a kérdésre, hogy mi alapján választották ki ezeket, a megkérdezettek közül 12 fö $(5,3 \%)$ válaszolta azt, hogy reklámban látta, 32 fő (14\%) baráttól, ismerőstől hallott róla, 22 fö (10\%) olvasott utána, 2 főnek (1\%) pedig szakemberek javasolták a használatot. Az egyéb válaszadás lehetőségét 12 fő (5,3\%) jelölte meg, az ő válaszaik a következők voltak: a GooglePlay áruházban, interneten talált rá, ő is használja, már rajta volt a készüléken, testvérétől látta, saját ötlet alapján választotta a gyermek érdeklődési körének megfelelően.

\section{A digitális eszközhasználat összefüggései a családi háttérrel}

Kérdőívünkben nem csak a gyermekek, hanem a szülők digitális eszközhasználatára is rákérdeztünk, különválasztva az egyéni és a gyermek jelenlété- 
ben vagy vele közösen történő használatot. A kérdések között megjelentek a posztolási szokások, illetve, hogy mely napszakokban használják eszközeiket leggyakrabban. Ezek közül először a megkérdezett szülők digitális eszközhasználatának célját ismertetjük, az erre vonatkozó kérdésnél több választ is meg lehetett adni, valamint egyéni válaszadásra is lehetőség volt.

\section{3. táblázat}

A kitöltők digitális eszközhasználati szokásai

\begin{tabular}{lcc}
\hline \multicolumn{1}{c}{ Digitális eszközhasználat } & Abszolút gyakoriság $\mathbf{( N )}$ & Relatív gyakoriság (\%) \\
\cline { 1 - 2 } $\begin{array}{l}\text { Kapcsolattartás } \\
\text { (telefon, video chat, chat) }\end{array}$ & 224 & 96,6 \\
$\begin{array}{l}\text { Fotó, videó készítése } \\
\begin{array}{l}\text { Hírolvasás, információkere- } \\
\text { sés, olvasás }\end{array}\end{array}$ & 197 & 84,9 \\
$\begin{array}{l}\text { Munkavégzés } \\
\text { Közösségi média használata }\end{array}$ & 174 & 81,9 \\
$\begin{array}{l}\text { Filmnézés, zenehallgatás, } \\
\text { játék }\end{array}$ & 172 & 75 \\
Egyéb & 125 & 74,1 \\
\hline
\end{tabular}

Amint az a 3. táblázatban is látható szinte az összes megkérdezett használja kapcsolattartásra (telefon, videohívás, chat) a digitális eszközét, ezt 224-en (96,6 \%) jelölték meg. Ez a pandémia alatt várható is volt. Ugyanilyen kiemelkedően magas arányt ért el a fotó, hír, munkavégzés és közösségi média. Ehhez képest némileg kevésbé jelent meg a filmnézés, zenehallgatás, valamint a játék kategóriája. Az egyéb opciót 8-an (3,4\%) töltötték ki, fényképnézegetést, számlabefizetést, online oktatást, tanulást, vásárlást és adás-vétel lebonyolítást jelöltek meg. Az online oktatást ketten, míg a többit egy-egy kitöltő válaszolta.

Külön kérdésként tettük fel azt, hogy gyermekeik jelenlétében hogyan és mire használják digitális eszközeiket. A válaszadásnál itt is több válasz megjelölésére volt lehetőség, valamint az egyéb opciónál egyéni válaszaikat is megadhatták. Az eredményeket a 4. táblázatban láthatjuk részletesen. 


\section{4. táblázat}

A kitöltök digitáliseszköz használati szokásai gyermekeik jelenlétében

\begin{tabular}{lcc}
\hline \multicolumn{1}{c}{ Digitális eszközhasználat } & Abszolút gyakoriság (N) & Relatív gyakoriság (\%) \\
\hline $\begin{array}{l}\text { Nem használja a gyermek } \\
\text { jelenlétében }\end{array}$ & 7 & 3,0 \\
$\begin{array}{l}\text { Kapcsolattartás } \\
\text { (telefon, video chat, chat) }\end{array}$ & 210 & 90,5 \\
$\begin{array}{l}\text { Fotó, videó készítése } \\
\text { Hírolvasás, információkeresés, } \\
\text { olvasás }\end{array}$ & 181 & 78 \\
Munkavégzés & 57 & 24,6 \\
Közösségi média használata & 60 & 25,9 \\
Filmnézés, zenehallgatás, játék & 54 & 23,4 \\
Egyéb & 48 & 20,7 \\
\hline
\end{tabular}

A gyermekkel történő használat során is legnagyobb számban - 210 fö (90,5\%) a kapcsolattartást jelölték meg, de hasonlóan magas arányt (78\%) mutat a fotó- és videókészítés kategóriája is. A hírolvasás, információkeresés, munkavégzés, közösségi médiahasználat, valamint a filmnézés, zenehallgatás közel azonos arányban jelentek meg. A kitöltők közül csupán 7 fó (3\%) válaszolta azt, hogy nem használja gyermeke jelenlétében az eszközt.

A kutatásban résztvevőket arról is kérdeztük, hogy a munkára fordított időn kívül körülbelül mennyi időt használják digitális eszközeiket. A kategóriák 1 órás intervallumban kerültek meghatározásra. A válaszadók közül legtöbben, 113-an (48,3\%) napi 1-2 órát, míg 75-en (32,1\%) 1 óránál rövidebb ideig használják eszközeiket. Kevesebb, azaz 29 szülő (12,4\%) választotta a napi 2-3 órát, míg 10 fö napi 3-4 óra közötti időt tölt képernyő előtt. A napi 4-5 óra közötti kategóriát 1 fó, míg az 5 óránál többet 2 fó válaszolta.

Rákérdeztünk a szülők posztolási szokásaira is, mely kérdés a közösségi média felületeire való családi fotók feltöltésének gyakoriságát tárta fel. Erre vonatkozóan 225 kitöltő közül 71-en (31,5\%) válaszolták, hogy nem szoktak közösségimédia-felületre fotókat feltölteni, 145-en (64,4\%), hogy alkalmanként, 5 -en (2\%), hogy hetente, 4-en (1,7\%), hogy hetente többször. A naponta többször és a naponta egyszer válaszokat senki nem jelölte meg. Az eredményekből kirajzolódik, hogy a válaszadók több mint fele alkalmanként szokott posztolni családjáról és több mint negyedük pedig egyáltalán nem szokott élni a posztolás lehetőségével.

A kérdőívben kitértünk a szokások napszakonkénti bontására is, mivel feltételeztük, hogy ezekben lesz eltérés. Többszörös választással jelölhettek meg hét lehetőséget arra a kérdésre, hogy „Mikor használja leggyakrabban eszközeit?’. Az eredményeket tekintve elmondhatjuk, hogy a szülők az esti 
órákban használják leginkább eszközeiket, a 229 kitöltő közül 72 fó $(31,4 \%)$, míg a változó használatot 63 fó $(27,5 \%)$ jelölte. A nincs kiemelt napszak lehetőségét 42-en (18,3\%) jelezték vissza, és 39-en éltek a több választás lehetőségével, melyből jellemző kombináció nem rajzolódott ki.

A családi háttér és eszközhasználati szokásokra összefüggéseinek ellenőrzéséhez megvizsgáltuk a képernyőidő, valamint az eszközhasználat gyakorisága és a kérdőívben gyüjtött egyes háttérváltozók közötti kapcsolatot. Spearman korrelációs elemzést végeztünk a hétköznapi és hétvégi képernyőidő kapcsolatának kimutatásához a szülők iskolai végzettségével, valamint az otthon található könyvek számával, aminél egyik esetben sem találtunk szignifikáns összefüggést ( $>>0,05)$. Utóbbi két háttérváltozónál Khi-négyzet próbával elemeztük az eszközhasználat gyakoriságával való összefüggéseket, a vizsgálatok egyik esetben sem mutattak ki szignifikáns kapcsolatot $(\mathrm{p}>0,05)$.

\section{A szülők prevencióról és szabályokról való véleménye}

Kiemelt célkitűzésünk volt feltárni a szülők véleményét a digitális eszközök gyermekükre gyakorolt hatásáról, emellett a témával kapcsolatos prevenciós nézeteiket is meg akartuk ismerni. Felmérésünk befejező, harmadik részében kaptak helyet az erre vonatkozó kérdések. Felmértük, milyen korban javasolják az eszközzel való megismerkedést, valamint a szülők nézeteit arra vonatkozóan, hogyan vélekednek a digitális eszközök lehetséges hatásairól.

Elsőként szerettük volna megtudni, hogy tájékozódnak-e a szülők a digitális eszközök esetleges hatásairól, mielőtt azt gyermekeiknek adják. A 234 kitöltőből 195 fö (83\%) válaszolt igennel, és 29 fö (12\%) adott nemleges választ. Arra a kérdésre, hogy hallottak-e már arról, hogy mennyi képernyőidő javasolt a 0-3 éves korosztálynak 140 fő (60\%) válaszolta, hogy hallott róla és be is tartják az ajánlásokat, míg 31 fő (13\%) szintén hallott róla, de nem tartják be azokat. A kutatásban résztvevő szülők közel negyede, 56 fö (24\%) nem hallott még az említett ajánlásról.

Kíváncsiak voltunk arra is, vannak-e szabályok a gyermekek digitális eszközhasználatával kapcsolatban. A családok zömében vannak szabályok a digitális eszközök használatra vonatkozóan, a különbség abban mutatkozik meg, hogy azok mire vonatkoznak. A legtöbb szülő - 88 fö (39\%) - időkorlátra vonatkozó szabályokat fogalmazott meg, míg 51 fó (22\%) mondta azt, hogy kizárólag kapcsolattartásra használhatja gyermeke az eszközt. Azonos számban 33 fö (15\%) jelölték a feltételhez (például „ha megetted az ebédet”), valamint a bizonyos napszakhoz kötött használatot. További 26 fö (11\%) válaszából az derült ki, hogy nincsenek szabályok az eszközhasználatot illetően.

Likert-skála segítségével mértük fel a szülők vélekedését arra vonatkozóan, hogy szerintük mely életkor lenne a legoptimálisabb a gyermekek számára a digitális eszközök megismerésének kezdő lépéseire. 1-5-ig terjedő skálán pontozhatták, mennyire értenek egyet a felsorolt állításokkal. A szülők erre vonatkozó nézeteit az 5 . táblázat mutatja be. 


\section{5. táblázat}

A kitöltök nézetei arra vonatkozóan, mikor ismerkedjen meg a gyermek a digitális eszközzel

\begin{tabular}{l|c|c}
\hline \multicolumn{1}{c|}{ Állítás } & Átlag & Szórás \\
\hline $\begin{array}{l}\text { Az a jó, ha a gyermekek minél korábban megismer- } \\
\text { kednek a digitális eszközökkel. }\end{array}$ & 2,1 & 1,1 \\
$\begin{array}{l}\text { Az a jó, ha a gyermekek minél korábban megismer- } \\
\text { kednek a digitális eszközökkel, de csak felnőtt jelenlé- } \\
\text { tében használhatják. }\end{array}$ & 2,8 & 1,3 \\
$\begin{array}{l}\text { Az a jó, ha a gyermekek minél korábban megismer- } \\
\text { kednek a digitális eszközökkel, de csak ellenőrzött } \\
\text { tartalmakat használhatnak. }\end{array}$ & 3,2 & 1,4 \\
$\begin{array}{l}\text { Az a jó, ha a gyermekek minél később ismerkednek } \\
\text { meg a digitális eszközökkel. }\end{array}$ & 3,6 & 1,3 \\
\hline
\end{tabular}

Az első állítással, mely a digitális eszközök minél korábban történő megismerésére vonatkozott kevésbé értettek egyet a szülők, az ötös skálán mért átlagérték 2,1. A 234 kitöltőből 92 fö (40\%) egyáltalán nem, 5 fö (2\%) teljesen mértékben egyetértett a mondat tartalmával, míg viszonylag jelentős számban 77 fó (33\%) semleges véleményt fogalmazott meg. A második állításban a digitális eszközök felnőtt jelenlétében történő használatát pontozhatták a szülők, ennek átlaga szintén alacsony értéket $(2,8)$ mutat. A válaszadók közül 53 fő (23\%) egyáltalán nem értett egyet vele 58 fö (25\%) semleges választ adott, 40 fö (17\%) teljesen egyetértett az állítással. A harmadik állítás a korai eszközhasználatot és annak ellenőrzöttségét mérte fel, a kitöltők közül 62 fö (27\%) teljes mértékben, 43 fö (18\%) egyáltalán nem értett egyet, és 46 fö (20\%) számára közömbös volt ez az állítás. Azzal a kijelentéssel értettek leginkább egyet a szülők, hogy minél később ismerkedjen meg a gyermek a digitális eszközökkel, ennek átlagértéke 3,6. A válaszadók közül 82 fő (35\%) teljesen egyetértett, míg 18 fö (8\%) egyáltalán nem értett egyet vele.

Az eredményekből az látszik, hogy a kérdőívet kitöltő szülők abban egyetértenek, hogy az a jó, ha a gyermekek minél később ismerkednek meg a digitális eszközökkel. Azonban, ha már ismeri az eszközt, akkor azt csak felnőtt jelenlétében használja, és csak ellenőrzött digitális tartalmakat fogyasszon.

A kérdőív további részében megfogalmazott állítások a digitális eszközök gyermekekre gyakorolt hatásaira vonatkoznak. E kérdéskör felmérésére ismét ötfokozatú Likert-skálát alkalmaztunk, eredményeit a 6. táblázat mutatja.

Az első állítással 64 fő (27\%) értett teljesen egyet, tehát a megkérdezett szülők negyede nem támogatja a digitális eszközhasználatot 3 éves kor alatt, míg 67 fö (29\%) semleges választ adott, az átlagérték 3,2. A második kijelentés 2,5-ös átlag mellett polarizáltabb képet mutat azzal kapcsolatban, hogy a gyermekeknek minél korábban meg kell ismerkedniük a digitális eszközökkel. A válaszadók közül 12 fö (5\%) teljes mértékben, míg 59 fö (25\%) egyáltalán nem értett egyet az állítással. 
Digitális eszközhasználati szokások vizsgálata bölcsődés gyermekek és családjaik körében - Szülők kikérdezése a pandémia idején

\section{6. táblázat}

A kitöltök nézetei, arra vonatkozóan, milyen hatásai lehetnek a gyermekekre a digitális eszközöknek

\begin{tabular}{|c|c|c|}
\hline Állítás & Átlag & Szórás \\
\hline $\begin{array}{l}\text { A digitális eszközök használatát } 3 \text { éves kor alatt nem } \\
\text { támogatom. }\end{array}$ & 3,2 & 1,3 \\
\hline $\begin{array}{l}\text { A digitális eszközök életünk részei, ezért a gyermekek- } \\
\text { nek minél korábban meg kell ismerkedni velük. }\end{array}$ & 2,5 & 1,1 \\
\hline A digitális eszközök könnyen függőséget okoznak. & 4,6 & 0,7 \\
\hline $\begin{array}{l}\text { A digitális eszközök használata elveszi az időt a moz- } \\
\text { gástól. }\end{array}$ & 3,9 & 1,2 \\
\hline $\begin{array}{l}\text { A gyermekek életkorához igazodó megfelelő digitális } \\
\text { eszközök, applikációk használata fejlesztő hatású le- } \\
\text { het. }\end{array}$ & 3,6 & 1,1 \\
\hline $\begin{array}{l}\text { A digitális eszközök korlátlan használata negatívan } \\
\text { hathat a beszéd- és mozgásfejlődésre. }\end{array}$ & 4,2 & 1,1 \\
\hline $\begin{array}{l}\text { A nem ellenőrzött tartalmak már ilyen kis korban is } \\
\text { veszélyt jelentenek. (megijedhet, nyugtalan lehet) }\end{array}$ & 4,7 & 0,6 \\
\hline
\end{tabular}

Leginkább a harmadik állítással értettek egyet a szülők, miszerint a digitális eszközök könnyen függőséget okoznak. Átlagértéke az egyik legmagasabb 4,6. A kitöltők közül 172 fö (75\%) értett teljesen egyet ezzel, a teljes elutasítást senki sem jelölte meg. Szintén egyezett a szülők véleménye azzal kapcsolatban, hogy a digitális eszközök használata elveszi az időt a mozgástól, itt az átlagérték 3,9. A válaszadók közül 111 fö (48\%) teljesen egyetértett, míg 13 fó (5\%) egyáltalán nem értett egyet ezzel az állítással. Abban is egy véleményen voltak, hogy a gyermekek életkorához igazodó, megfelelő digitális eszközök, applikációk használata fejlesztő hatású lehet, itt az átlag 3,6 lett a skálán. A szülők közül 80 fö (78\%) nagyrészt egyetértett ezzel az állítással, 69 fö (30\%) adott semleges választ, 14 fó (6\%) egyáltalán nem értett egyet ezzel. Magas átlagértéket kapott $(4,2)$ az az állítás, amely arra vonatkozott, hogy a digitális eszközök korlátlan használata negatívan hathat a beszéd- és mozgásfejlődésre. A megkérdezettek közül 134 fö (58\%) értett teljesen egyet, 41 fö (18\%) nagyrészt egyetértett, míg 8 fö (3\%) egyáltalán nem értett egyet ezzel a kijelentéssel. Az utolsó állításnál volt a legnagyobb egyetértés a szülők között, hogy a nem ellenőrzött tartalmak már ilyen kis korban is veszélyt jelentenek a gyermekre. Szinte egységesen válaszoltak, 194 fö (84\%) egyetértett, csupán 3 fő (1\%) volt, aki nem így gondolta. Így az itt kapott 4,7-es átlagérték lett a legmagasabb.

A kérdőív prevenciós részének zárásaként a szülőket megkérdeztük arról is, hogy mennyi időben maximalizálnák a napi digitális eszközhasználatot különböző életkorú gyermekek (1 éves kor alatt, 1-2, illetve 2-3 éves 
korú gyermek) esetében. A kitöltők közül 1 éves kor alatt 169 fö (72\%) egyáltalán nem javasolná a gyermekek digitális eszközhasználatát, 48 fő (21\%) 30 percnél kevesebbet, míg 13 fö (6\%) 30-60 perc közötti időtartamot tartana helyesnek. Az 1-2 éves korosztálynak 83 fö (36\%) nem javasolná, 101 fő (44\%) 30 percnél kevesebbet ajánlana, míg 43 fó (19\%) 30-60 perc közti időszakot tartana helyesnek. További 2 fö $(0,9 \%) 60$ perc fölött jelölte meg az eszközhasználat ajánlott időtartamát. A 2-3 éves gyermekre vonatkozóan 35 fö (15\%) még ebben a korban sem javasolná az eszközhasználatot, 92 fő (40\%) 30 percnél kevesebbet, 88 fö (38\%) 30-60 perc közti időtartamot tartana helyesnek, míg 12 fö (5\%) 60 perc fölött határozná meg a napi digitális eszközhasználatot.

\section{Diszkusszió}

A kisgyermekek digitális eszközhasználata egy új és vitatott területe mind a pszichológiai, mind pedig a neveléstudományi kutatásoknak. A témában eddig megjelent kutatások szerint a digitális eszközhasználatnak és tartalomfogyasztásnak nincsen kialakult szokásrendszere a kisgyermekes családokban (Konok et al., 2020). A szülők nem minden esetben vannak tisztában a kisgyermekekre leselkedő veszélyekkel, esetleges kockázatokkal, miközben számos kutatás rámutatott arra, hogy a szülőknek és a gyermekekkel foglalkozó szakembereknek egyaránt határozott igénye van a megfelelő eszközhasználati szokások ismeretére és tanítására (Chaudron et al., 2020). Ennek ismeretében határoztuk meg kutatásunk céljait azért, hogy pontosabb képet kapjunk a hazai bölcsődei ellátásban résztvevő gyermekek digitális eszközhasználatáról, valamint, hogy megvizsgáljuk, a különböző szocioökonómiai tényezők milyen kapcsolatot mutatnak a gyermekek digitális eszközhasználatával. További célunk volt, hogy megismerjük a szülők véleményét, ezen készülékek gyermekükre gyakorolt hatásáról, valamint információt szerettünk volna kapni a szülők prevenciós/produktív eszközhasználati nézeteiről. A vizsgálatunkhoz papíralapú kérdőívet alkalmaztunk, ezért fontosnak tartottuk a kialakult járványügyi helyzetben - a bölcsődékbe nem lehetett külsős személynek bemenni -, hogy legyen személyes kapcsolatunk az intézményekkel.

A kitöltők 53\%-a felsőfokú végzettségű, ami a 2016. évi mikrocenzus adatai szerint is a diplomával rendelkezők erős felülreprezentálását jelenti, mivel a teljes népességben ez az arány mindössze $22 \%$. A településtípusokat tekintve a főváros - nagyváros - kisváros volt hangsúlyos. Bár célunk volt a településtípusok és az iskolai végzettség közötti esetleges összefüggések feltárása, a mintában kialakult aránytalanságok miatt erre nem volt lehetőségünk, így összességében eredményeinket nem tekinthetjük reprezentatívnak. Kérdőíves vizsgálatunk további korlátjának tekinthető, hogy a kutatáshoz készített kérdőív több kérdése is szülői becslésre, egyéni megítélésre irányul, melyek eredményei tartalmazhatnak szubjektív és elvárásoknak megfelelő válaszo- 
kat az anonimitás megléte mellett is. Jelen esetben a 0-4 éves korú gyermekek, de hasonló korosztály esetében az alkalmazott kérdőíves adatfelvételi módszernél jelen van ez a torzító tényező (Koscsóné Kolkopf, 2020), ugyanakkor megjelentek olyan kutatási módszerek, melyek kizárják ezt a torzító hatást (például Konok et al., 2020).

Vizsgálatunk alapján beigazolódott, hogy a bölcsődei ellátásban részesülő gyermekek egyre korábban ismerkednek meg és egyre hosszabb időintervallumban használják a digitális eszközöket. Elmondhatjuk, hogy a megkérdezett szülők gyermekeinek $85 \%$-a már 24 hónaposan, tehát 2 évesen vagy azt megelőzően került közvetlen kapcsolatba digitális eszközök valamelyikével, viszont a különböző szocioökonómiai tényezők (például könyvek száma) és a gyermekek digitális eszközhasználata között a vizsgált populációban nem találtunk összefüggéseket.

Első kutatási kérdésünk arra vonatkozott, hogy mikor jelent meg először a vizsgált gyermekek életében valamelyik digitális eszköz. Eredményeink szerint 200 kitöltő gyermeke már 24 hónaposan, tehát 2 évesen vagy azt megelőzően került közvetlen kapcsolatba digitális eszközzel, ami a megkérdezett szülők gyermekeinek 85\%-át jelenti. Ez az érték jelentősen meghaladja az ELTE Alfa Generáció Labor kutatási eredményeit, ahol azt állapították meg, hogy a vizsgált gyermekeknek a fele már 2 éves kortól kütyüzik (Konok et al., 2018). A válaszadók gyermekeinek 5,6 \%-a (13 gyermek) még nem került kapcsolatba digitális eszközzel.

Következő kutatási kérdésünk arra vonatkozott, hogy milyen gyakran és mennyi időt használják a családban előforduló digitális eszközöket a bölcsődés korú gyermekek. A napi használat az okostelefonok esetében mutatta a legmagasabb értéket (34 gyermek), majd a tablet (14 gyermek), és a laptop (9 gyermek) következett. A heti és hetente többszöri használat kapcsán is ez a sorrend a jellemző. A személyi számítógép, okosóra, e-book használata a korosztály szempontjából elhanyagolható. Az „egyéb” eszközként a televízió jelent meg itt is minden esetben napi használat a jellemző. Eredményeink megegyeznek a Digitális Honfoglalás címü (Koscsóné Kolkopf \& Kiss, 2020) kutatásban foglaltakkal, miszerint a digitális eszközök közül a gyermekek életében az okostelefonok és a tabletek bírnak meghatározó jelentőséggel.

A képernyő előtt töltött időtartamra vonatkozóan 184-en (82,9 \%) azt válaszolták, hogy gyermekük napi 1 óránál kevesebbet tölt a digitális eszközök valamelyikével, 29 gyermek (13\%) napi 1-2 órát használja a kütyüket, és összességében 9 gyermek (4,1 \%) esetében jelöltek meg naponta 2 óránál hosszabb képernyőidőt.

A szülők és gyermekeik tartalomfogyasztására leginkább internet-alapú használat a jellemző. Az eszközök használati céljára megfogalmazott kérdéseink eredményei azt mutatták, hogy elsődlegesen kapcsolattartásra (96,6\%), fotózásra $(84,9 \%)$ és információkeresésre (84,9\%) használják az eszközöket, de a szülők jelentős arányban (75\%) a munkavégzést és a közösségi médiahasználatot $(74,1 \%)$ is megjelölték. A szülők több mint fele 125 fő $(53,9 \%)$ 
a filmnézést és 8 fő $(3,4 \%)$ az egyéb opciót választotta, melynél fényképnézegetést, számlabefizetést, online oktatást, tanulást, vásárlást és adás-vétel lebonyolítást jelöltek meg. Az eredményekből egyértelműen kiderül, hogy a digitális eszközök a mindennapi élet segítőjeként, munkavégzés és szórakozás céljából vannak jelen a válaszadók életében.

A digitális eszközhasználat tudatosságára vonatkozó kérdések segítségével célunk volt feltárni a szülők véleményét a digitális eszközök gyermekükre gyakorolt hatásáról, valamint prevenciós eszközhasználati nézeteikről, arról, tájékozódtak-e az eszközök esetleges hatásairól, mielőtt azt gyermekeiknek adták. Az eredmények azt mutatják, a szülők tudatosak ezen a téren, hiszen 83\%-uk informálódott az esetleges következményeket illetően, és tisztában vannak a 0-3 éves korosztálynak javasolt képernyőidővel, illetve szabályokat állítottak fel, mielőtt gyermeküknek adták az eszközt. A gyermekek naponta 1 óránál kevesebbet ugyan, de időt töltenek az eszközzel, azonban azt felnőtt jelenlétében használják és ellenőrzött digitális tartalmakat fogyasztanak. Leginkább mesét néznek és távoli rokonokkal való kommunikációra használják a digitális eszközöket.

Az elmúlt időszak - a járványügyi helyzet - komoly kihívások elé állította az eszközhasználatról tudatosan gondolkodó szülőket is, de ennek hatása még kevésbé érzékelhető az eredményekből, melyek azt mutatják, hogy a kutatásban vizsgált szülők zömének is fontos a tudatos eszközhasználat, a képernyő előtt eltöltött idő és tartalom korlátozása. Ebben már segítséget nyújthatnak különböző applikációk is, melyeket mindenképpen érdemes használni annak fényében, hogy a gyermekgyógyászokat tömörítő szervezetek (Amerikai Gyermekgyógyászati Akadémia 2016; Kanadai Gyermekgyógyászati Társaság 2017) úgy látják, szükséges korlátozni a gyermekek napi képernyőidejét. Javaslatukat azzal indokolják, hogy a valós, nem virtuális térben zajló interakciók pozitívabb hatást gyakorolnak a gyermekek fejlődésére és jólétére (Hódi et al., 2019). Gyermekkorban fontos fejlődési szakasz a szimbolikus gondolkodás és annak megélése, a szimbolikus játék. A gyermek saját maga által kigondolt szerepjáték és annak eljátszása az ő problémáinak megélését, frusztrációinak feldolgozását jelenti. Ha a digitális eszközök használatából eredően különböző játékokkal, videókkal és egyéb hasonló tartalmakkal nagyobb arányban kerül kapcsolatba, a fent említett szimbolikus játék kimarad, vagy nagyon csekély mértékben lesz jelen, ezért önmagával kevesebb "munkát folytat lelkileg" ez pedig nehezebben szocializálódó, érzékenyebb és feszültebb viselkedéshez vezethet (Fejérváry, 2020).

A szülők véleménye egyezett abban, hogy jobb, ha a gyermekek minél később ismerkednek meg a digitális eszközökkel. Ezek a készülékek könnyen függőséget okoznak, elveszik az időt a mozgástól, illetve negatívan hatnak a gyermek beszéd- és mozgásfejlődésére, a nem ellenőrzött tartalmak pedig már ilyen kis korban is veszélyt jelentenek a gyermekek számára. Közös álláspontot képviseltek abban is, hogy a gyermekek életkorához igazodó, megfelelő digitális eszközök, applikációk használata akár fejlesztő hatású is lehet. 
Az életkornak, a minőségi és a mennyiségi mutatóknak azonban hangsúlyos szerepük van ezzel kapcsolatban, mert a kutatási eredmények a gyermekek fejlődését veszélyeztető kockázatokat valószínűsítenek az érintőképernyős eszközök és multimédia-készülékek korai használata során. Nem beszélve arról, hogy a 18 hónapos korban vagy már korábban képernyős eszközöket használó gyermekek jóval magasabb arányban mutatnak nyelvfejlődési késést (Fehérné Kovács et al., 2018).

Kutatásunkban törekedtünk árnyalt képet adni a hazai bölcsődei ellátásban résztvevő gyermekek digitális eszközhasználatáról. A kérdőívet kitöltők alacsony száma (234 fö), életkori eloszlása (65\%-ban 31-40 év közötti) nemük, és iskolai végzettségük aránya miatt kutatási eredményeink kizárólag a 234 kitöltőre vonatkozó megállapításokat tartalmaznak, mintánk nem reprezentálja a választott településeken élő szülőket és családokat. Bár vizsgálatunk nem volt reprezentatív, mégis fontos információkat tudhattunk meg a bölcsődés korú gyermekeket nevelő családok digitális eszközhasználati szokásairól, valamint arról, hogyan vélekednek a szülők ezeknek az eszközöknek a gyermekükre gyakorolt hatásairól, mennyire tudatosan használják ezeket.

\section{Összefoglalás}

Kutatásunk célja volt, hogy pontosabb képet kapjunk a hazai bölcsődei ellátásban résztvevő gyermekek és családjuk digitális eszközhasználati szokásairól, továbbá érdeklődésünk fókuszában állt a szülők vélekedéseinek feltérképezése a digitális eszközök gyermekükre gyakorolt hatásáról, valamint prevenciós/ produktív eszközhasználati nézeteikről. Kutatási eredményeink szerint már a bölcsődés korosztályú gyerekek is nagy arányban találkoztak és ismerik a digitális eszközöket, használják is azokat, ugyanakkor legnagyobb arányban szüleik jelenlétében történik a digitális eszköz használata. Tartalomfogyasztási szokásaikról elmondható, hogy leginkább meséket-mozgóképes tartalmakat fogyasztanak, használati szokásaikról pedig, hogy legnagyobb arányban rokonokkal való kapcsolattartásra használják az eszközöket. Kutatásunkból az is kiderül, hogy a szülők nagy része úgy gondolja, a digitális eszközökkel való minél későbbi találkozás a legmegfelelőbb a gyermekek számára, továbbá a válaszadók túlnyomó többsége 1 éves kor alatt nem is javasolná használatukat, ugyanakkor a kérdőívben adott válaszokból megállapítható, hogy a gyermekek már 6-24 hónapos koruk között kapcsolatba kerültek az eszközökkel, valamint napi szinten az életük részeként jelen vannak azok. A szülők prevenciós nézeteiről elmondható, hogy leginkább időbeli korlátokkal próbálják szabályozni az eszközhasználatot, de kialakult és tudatos szabályrendszer, illetve preventív nézetek csak kis mértékben kapnak szerepet a szokásaikban és azok alakításában. Az esetleges kockázatok nem minden esetben kapnak kellő hangsúlyt, miközben számos kutatás mutatott rá arra, hogy a szülőknek és a gyermekekkel foglalkozó szakembereknek egyaránt határozott igénye van a megfelelő eszközhasználati szokások ismeretére és tanítására. 
A digitális eszközök előnyei és hátrányai egyaránt jelen vannak életünkben, pedagógiai munkánk során is. Használatukkal az életünk és munkánk számos területen pozitív irányban változott és változik jelenleg is, a digitális eszközökkel számos előnyre tehetünk szert. Ezért is fontos pedagógiai szempontból a produktív használati szokások kialakítása, módszertani ajánlások beemelése a napi gyakorlatba (Németh et.al., 2020; Visnjic-Jevtic et. al., 2021), mert a megfelelő és biztonságos használat közös érdekünk, ennek segítségével a korai életkorban történő szokások kialakítása, a produktív használatra nevelés sokkal eredményesebb lehet. A módszertani ajánlás a bölcsődékben segítségére lehet a kisgyermeknevelőknek, pedagógusoknak és egyéb szakmai szolgáltatást nyújtó szakembereknek, ugyanis a gyermekek életében ez a korai életszakasz első intézményesült szociális színtere. Kutatásunk véleményünk szerint - hasznos adaléka és kiindulópontja lehet további, akár szorosan, akár lazábban kapcsolódó témában történő kutatásoknak. Úgy gondoljuk, hogy az eltérő fejlődésmenetü, és/vagy sérült gyermekek megfelelő pedagógiai felügyelettel ellátott digitális eszközhasználatában sok lehetőség rejlik. Gondolunk itt például eszközzel támogatott fejlesztésre, amely segítségül szolgált már kommunikációban a mozgássérült, illetve egyéb pszichés zavarral küzdő és autizmus spektrumzavarral élő gyermekek esetében, valamint a tableten történő jelnyelv tanítására/tanulására alig- vagy egyáltalán nem beszélő gyerekek esetében (Hsieh, 2008).

A tanulmány az Innovációs és Technológiai Minisztérium ÚNKP-20-5 kódszámú Új Nemzeti Kiválóság Programjának a Nemzeti Kutatási, Fejlesztési és Innovációs Alapból finanszírozott szakmai támogatásával készült

\section{Irodalom}

Burroughs, B. (2017). YouTubekids: The appeconomy and mobile parenting. Social media + society, 3(2). https://doi.org/10.1177/2056305117707189

Chaudron, S. (2015). Young Children (0-8) and digital technology: A qualitative exploratory study across seven countries. JRC; ISPRA. https://publications.jrc. ec.europa.eu/repository/handle/JRC93239, https://doi.org/10.2788/00749

CsapónéF.Sz.(2019).Szülőktámogatásaakisgyermekekmegfelelőmédiahasználatában. In Fehér, Á. \& Megyeriné, R, A. (Eds.), A digitális világ hatása a gyermekekre - III. Nemzetközi Kisgyermek-nevelési Konferencia kötete. (p. 21). Apor Vilmos Katolikus Föiskola.

Detnakarintra, K., Trairatvorakul, P., Pruksananonda, C. \& Chonchaiya, W. (2020). Positive mother-child interactions and parenting styles were associated with lower screen time in early childhood. Acta Paediatrica, 109(4), 817-826. https:// doi.org/10.1111/apa.15007

Fehér, Á. \& Megyeriné Runyó, A. (2019, Eds). A digitális világ hatása a gyermekekre. III. Nemzetközi Kisgyermek-nevelési Konferencia. Apor Vilmos Katolikus Főiskola. 
Fejérváry, K. (2020). Cybergyerekek. Demokrata, 2020.10.16. https://demokrata.hu/ tudomany/cybergyerekek-299920/

Gálik, M. \& Csordás, T. (2020, Eds.). A média gazdaságtanának kézikönyve. Nemzeti Hírközlési és Média Hatóság, Médiatudományi Intézet.

Google Play Áruház. Digitális jóllét. https://play.google.com/store/apps/details?id= com.google.android.apps.wellbeing\&hl=hu\&gl=US

Hódi, Á., Tóth, E., B Németh, M. \& Dombi, A. (2019). Óvodások IKT-használata otthon-szülői minta és szerepvállalás. Neveléstudomány, 7(2), 22-41. https:// doi.org/10.21549/NTNY.26.2019.2.2

Hsieh, H. C. (2008). Effects of ordinary and adaptive toys on pre-school children with developmental disabilities. Research in Developmental Disabilities, 29(5), 459-466. https://doi.org/10.1016/j.ridd.2007.08.004

Konok, V., Bunford, N. \& Miklósi, Á. (2020). Associations between child mobile use and digital parenting style in Hungarian families. Journal of Children and Media, 14(1), 91-109. doi.org/10.1080/17482798.2019.1684332

Koscsóné Kolkopf, J. \& Kiss, H. (2020). „Digitális Honfoglalás” avagy 0-3 évesek a digitális világban. Gyermeknevelés Tudományos Folyóirat, 8(2), 202-218. https:// doi.org/10.31074/gyntf.2020.2.202.218

Fehérné Kovács, Z., Kas, B. \& Pintye, M. (2018). Szempontok a nyelv-és beszédfejlődési zavarok szüréséhez és állapotmegismeréséhez. Családbarát Ország Nonprofit Kft.

KSH (2017): Távközlés, televízió- és internetszolgáltatás - IKT-eszközök és használatuk a háztartásokban, a vállalkozásoknál és a közigazgatásban, 2017. Központi Statisztikai Hivatal. http://www.ksh.hu/docs/hun/xftp/idoszaki/ikt/ ikt17.pdf

Lénárd, A. (2015). A digitális kor gyermekei. Gyermeknevelés Tudományos Folyóirat, 3(1), 74-83.

Magyarország Digitális Gyermekvédelmi Stratégiája (2016). Digitális Jólét Nonprofit Kft., https://digitalisjoletprogram.hu/files/86/ d8/86d889e8f382b45b80bcca4d5945bbca.pdf?fbclid=IwAR1x4LjGjgo_ jUoR7X50QTuW91Rd9HSTq0HcgsIbtMTx8SS6yB610JkUqig

Nemzeti Média-és Hírközlési Hatóság (2018). A három éven aluli gyermekek médiahasználati szokásai. http://nmhh.hu/dokumentum/195599/3_even_ aluliak_mediahasznalata.pdf

Németh, I. P., Bacsa-Bán, A., Rajcsányi-Molnár, M. (2020, Eds.): Civil Szemle Különszám. Oktatás, digitalizáció, civil társadalom. Civil Szemle Alapítvány, . https://ktk.pte.hu/sites/ktk.pte.hu/files/uploads/FlowMare\%20publikaciok/ CSz\%20k\%C3\%BCl\%C3\%B6nsz\%C3\%A1m\%20el\%C5\%91lappal.pdf

Orlowski, J. (2019, rendezö). Társadalmi dilemma (film). Netflix Inc., Los Gatos.

Rausch, A. \& Pásztor, A. (2021). Mobil eszközök az óvodában: A digitális technológiával támogatott értékelés és fejlesztés lehetőségei. Neveléstudomány, 9(3), 5-17. https:// www.doi.org/10.21549/NTNY.33.2021.2.1 
Steyer, J. P. (2012). Szólj vissza a facebooknak! Gyakorlati útmutató a gyerekneveléshez a digitális korszakban. GABO Kiadó Kft.

Stienwandt, S., Cameron, E. E., Soderstrom, M., Casar, M. J., Le, C. \& Roos, L. E. (2020). Keeping Kids Busy: Family Factors Associated with Hands-on Play and Screen Time During the COVID-19 Pandemic. https://doi.org/10.31234/osf.io/ prtyf

Tsouklidis, N., Tallaj, N., Tallaj, Y. \& Heindl, S. E. (2020). Lights Out! The Body Needs Sleep: Electronic Devices and Sleep Deficiency. Cureus, 12(7). https://www.doi. org/10.7759/cureus.9292

Visnjic-Jevtic, A., Varga Nagy, A., Ozturk, G., Şahin-Sak, İkbal T., Paz-Albo, J., Toran, M. \& Sánchez-Pérez, N. (2021). Policies and practices of early childhood education and care during the COVID-19 pandemic: Perspectives from five countries. Journal of Childhood, Education \& Society, 2(2), 200-216. https://doi.org/10.37291/2717638X.202122114 


\section{Farkas, P., Schreindorfer, L. A., Szabó, G., Varga, Gy. \& Rausch, A.}

\section{The use of technology of children in nursery care}

The use of technology in early childhood children is a new and controversial area of psychological and educational research, there are no established habits for using these tools and for the consumption of digital contents (Konok, Bunford, \& Miklósi, 2020). Parents are not always aware of the dangers and potential risks of technology, while both parents and professionals have need to know and teach appropriate use habits for children (Chaudron et al., 2020). The aim of our research was to get an accurate picture of the digital device use of young children in nursery care and to explore the relationship between different socio-economic factors and children's use of ICT. In addition, we wanted to explore parents' opinions on the impact of digital tools on their children, and we also wanted to find out their views on preventive / productive ICT use. For our study, we used a paperbased questionnaire filled out by 234 parents raising children in nursery care. This research shows the main characteristics of the digital technology use of the families with young children and creates an opportunity for professionals to formulate recommendations for a preventive approach to the use of digital technology in early childhood.

Keywords: digital technology, children, ICT use, mobil devices 